Nepal Journal of Multidisciplinary Research (NJMR)

Vol. 3, No. 1, June 2020. Pages. 1-6

ISSN: 2645-8470 (Print), ISSN: 2705-4691 (Online)

DOI: https://doi.org/10.3126/njmr.v3i1.30213

\title{
Ayurvedic Approach on COVID-19 Prevention and Care
}

\author{
Dr. Pramod Bhatta \\ Ayurveda Campus \\ Institute of Medicine, Tribhuvan University \\ Email: pramodbhatta1966@gmail.com
}

Received: June 10, 2020; Revised \& Accepted: July 12, 2020; Published: July 14, 2020

(C) Copyright: Bhatta (2020).

(c) (1)

This work is licensed under a Creative Commons Attribution-Non Commercial 4.0 International License.

\begin{abstract}
CoVID-19 caused pandemic taking lives of more than 551,046 resulting massive physical, psychological, economical loss around the world. Various aspect of epidemic is described in Ayurveda. The study aims to identify the components which can help preventing and caring from Corona Virus and COVID-19. Based on textual and research of previous literatures, the finding is suggestive of by applying the Ayurvedic approach to prevent and care of proper adaptation of health behavior will support preventing the disease and minimize the complications.
\end{abstract}

Keywords: Ayurvedic approach, Corona Virus, COVID-19, Prevention and Care

\section{Introduction}

History of Corona virus is very old, from literatures in 1930s first coronavirus was discovered in chickens whereas in human it was detected in 1960s. Moreover, among family of hundreds of viruses the research findings, there are seven coronaviruses which are capable to cause disease in humans. Among them three can cause much more serious and even fatal disease (The Conversation, 2020).

In recent days the pandemic caused by the coronavirus name given SARS-CoV-2 had almost paralyzed whole world. According to World Health Organization report, as of day July 10, 2020 there 12,102,328 confirmed COVID-19 Cases and 551,046 deaths worldwide (World 


\section{Nepal Journal of Multidisciplinary Research (NJMR) \\ Vol. 3, No. 1, June 2020. Pages. 1-6 \\ ISSN: 2645-8470 (Print), ISSN: 2705-4691 (Online) \\ DOI: https://doi.org/10.3126/nimr.v3i1.30213}

Health Organization, 2020). This data shows that COVID-19 pandemic become a great threat to mankind with Physical, Mental, Social and Economic loss. Furthermore, spotlight report also showed similar finding that the fear of COVID-19 impacted on people's social, physical, psychological and economical aspects (https://www.spotlightnepal.com/2020/04/03/covid19-street-effects/, 2020). Nepal is also severely suffering from the COVID-19 pandemic. As of the national data from Ministry of Health and Population, Nepal (MoHP) more than 16,649 new nCoV2 infected new cases with 35 deaths as of date July 10, 2020 (Ministry of Health and Populaltion, Nepal, 2020).

Major threat of this virus is its changing strain than its original form. From the article where scientist found and believe that, this mutation is approximately 10 times more infectious than the original viral strain (Terry, 2020). This made the difficulty on preparing vaccine and difficulty in treatment of COVID19. Ayurveda is one of the oldest practiced medical system in the world originated in eastern culture where it describes about prevention and treatment of different diseases. Mostly it is based on herbs, herbo-mineral components for treatment. It also provide guidelines for lifestyle modification to prevent and care diseases. Since prehistoric time the sages emphasized on the application of naturally occurring elements such as sunlight, yoga, pranayama, rasayans, healing property of plants etc. for human wellbeing. Based on Ayurvedic text several plants are being used since long for prevention and cure of various infectious diseases including viral diseases, some of which are Guduchi, amala, yesthimadhu, bhuiamalki, aswagandha, Tulsi etc. These could of better option to work against SARS-CoV-2 and COVID-19 if administered properly. Further it will also create ground for scientific research on the effectivity of herbs and Ayurvedic medicine. In this context this paper primarily focused on the objective on Ayurvedic approach to combat the pandemic to prevent and save the people.

\section{Methodology}

The review article is based on the secondary data from different Ayurvedic text books, journals, internet resources, electronic sources, personal experience and observation. This is analytical research which has analyzed the finding of various research articles related to the prevention and treatment of Corona Virus by applying the Ayurveda approach.

\section{Result and Discussion}

The typical signs of COVID-19 infection are fatigue, cough, fever, myalgia, and some patients have also developed dyspnea. Respiratory symptoms like cough, shortness of breath, acute respiratory syndrome and organ injury are also detected as serious complications (Dariya \& Nagaraju, 2020). In Ayurveda symptoms of Swine flu in resembles with Sannipataj Jvara.which is basically triggered by the aggravation of the three Doshas (Vata, 


\section{Nepal Journal of Multidisciplinary Research (NJMR) \\ Vol. 3, No. 1, June 2020. Pages. 1-6 \\ ISSN: 2645-8470 (Print), ISSN: 2705-4691 (Online) \\ DOI: https://doi.org/10.3126/njmr.v3i1.30213}

Pitta and Kapha) and loss of Ojas (immunity) in the body. According to National Health Portal, diseases are mostly caused due to loss of oja and weak mental strength. Hence Ayurveda strongly recommends the strengthening of the Ojas (immunity) to prevent diseases' (National Health Portal, India, 2015).

\section{Prevention and Treatment of Coronavirus}

Current clinical management includes infection prevention and control measures and supportive care, including supplemental oxygen and mechanical ventilator support when indicated (Center for Disease Control (CDC), 2020). The effectivity of treatment may enhanced if it can be integrated with Ayurvedic approach.

\section{Immunity against SARS CoV2}

Literature had already shown about potency of ayurvedic medicines against viral diseases. Following ayurvedic lifestyle, food guideline found effective against various viral disease. Corona also belongs to flu virus group. There is currently no evidence that people who have recovered from COVID-19 and have antibodies are protected from a second infection (World Health Organiztion, 2020). In this context also use of various medicinal plants seems important alternative in prevention and care of COVID-19.

According to Nile et al. treatment of COVID-19 cytokine storm focuses primarily on support and symptomatic treatment of inflammation of respiratory function (Nile, et al., 2020, Pages). In Ayurved, Bacopa monnieri has also been used in Ayurveda to treat inflammatory conditions. In modern biomedical studies, bacopa showed inhibition the release of proinflammatory cytokines TNF- $\alpha$ and IL-6 in biomedical research in animal models (Nemetchek, Stierle, Stierle, \& Lurie, 2016). Use of these plant can help reducing inflammation of respiratory function.

Ayurveda, the 'science of life' deals with a preventive and curative measures for the wellbeing of creature. Ayurveda describes Rasayana herbs that are believed to re-establish and detoxify the body and mind, prevent degeneration and delay aging or rather reverse the aging process. From the Rasayana treatment, one attains longevity, memory, intelligence, freedom from disorders, youthful age, excellence of luster, complexion and voice, oratory, optimum strength of physique and sense organs, respectability and brilliance (Pansare \& Thombare, 2016 ).

According to Anbazhagan et al. Boerhavia diffusa, Eclipta alba and Phyllanthus amarus have great potential in curing various viral infections. Observation showed drugs prepared from the herbs either single or in combination was effective in killing many viruses (Anbazhagan, Palaniyandi, \& Joseph, 2019) 


\section{Nepal Journal of Multidisciplinary Research (NJMR) \\ Vol. 3, No. 1, June 2020. Pages. 1-6 \\ ISSN: 2645-8470 (Print), ISSN: 2705-4691 (Online) \\ DOI: https://doi.org/10.3126/nimr.v3i1.30213}

Ayurveda, the traditional Indian system of medicine has given great emphasis to the promotion of health. Ayurveda therapies are based on restoration of body balance and nourishment of dhatus or tissues. Rasayana concept of Ayurveda explains tissue regeneration and cell renewal. The drugs and therapies explained as rasayana provide research opportunities for biology of regeneration. Specific rasayana stimulate and nourish respective dhatus. Interpretation of this description offers clues for specific differentiation of stem cells with appropriate extract. The preliminary experiments on Medhya drugs suggest neuronal stem cells differentiation. Authors highlight the potential of Ayurveda and its possible contributions in regenerative medicine. Authors propose a protocol based on integrative approach derived from Ayurveda concepts and current understanding of regenerative medicine. The advanced understanding about adult and embryonic stem cells along with concepts of regeneration in Ayurveda has immense potential in the development of regenerative medicine.

Immunity is extremely important to prevent and care of Health. Which was also described in the article of Verma et al. saying the application of Amalaki Rasayana, Triphala Rasayana, Chyavanprash Rasayana etc. in Ayurveda for vitality and prolonging life (Verma, Goyal, \& Varsakiya, 2019).

As Dr. Vasant Lad mentioned in his lecture that "with pranayama we can clean our prana vaha srotas, our respiratory system and it will give us a boosting of energy so that we can keep away the virus" (The Ayurvedic Institute, 2020). In such alarming situation integration of Ayurvedic approach might be help to lower the burden of virus and disease COVID19.

\section{Conclusion and Recommendations}

The findings suggested the implementation of Ayurvedic approach activity along with its proper records and analysis of outcome for further research in Treating COVID 19. Which will help minimizing the morbidity, mortality and other losses. The findings also suggestive of further clinical application and outcome study in close monitoring adhered with standard treatment guideline and procedures.

Despite of several strategies from different countries in control, prevention and treatment strategies the problem of spreading morbidity and mortality is still very high worldwide. Although vaccine experimentation is under process but still promising result is awaited. In this situation research oriented Ayurvedic integration can be a better way in lowering the COVID-19 burden.

\section{Acknowledgement}

I would like to thank Dr. Tej Karki from bottom of my heart for his support in preparation of this article. 


\section{Nepal Journal of Multidisciplinary Research (NJMR) \\ Vol. 3, No. 1, June 2020. Pages. 1-6 \\ ISSN: 2645-8470 (Print), ISSN: 2705-4691 (Online) \\ DOI: https://doi.org/10.3126/njmr.v3i1.30213}

\section{Conflict of interest}

None

\section{References}

Anbazhagan, G. K., Palaniyandi, S., \& Joseph, B. (2019, June 17). Antiviral Plant Extracts. Retrieved from https://www.intechopen.com/books/plant-extracts/antiviral-plantextracts: https://www.intechopen.com

Center for Disease Control (CDC). (2020, April 25). https://www.cdc.gov. Retrieved from https://www.cdc.gov/coronavirus/2019-ncov/hcp/therapeutic-options.html: https://www.cdc.gov/

Dariya, B., \& Nagaraju, G. P. (2020). Understanding novel COVID-19: Its impact on organ failure and risk assessment for diabetic and cancer patients. Cytokine \& Growth Factor Reviews, 43-52.

Hasan, N., Hossain, S., \& Haque, M. A. (2020). Scope of Ayurvedic Medicine in Pneumonia Patients Visiting Govt. Hospitals in Bangladesh: A Cross-sectional Study. Journal of Complementary and Alternative Medical Research , 1-6.

Hazera, K. (2016). Punarnava (Boerhavia Diffuse Linn), A Worldwide Ethnomedical Used Herbs And Its Potentiality-An Ayurvedic Approch. International Journal of Ayurvedic and Herbal Medicine 6:1 , 2113 -2122.

https://www.spotlightnepal.com/2020/04/03/covid-19-street-effects/. ( 2020, April 3).

Retrieved from https://www.spotlightnepal.com: https://www.spotlightnepal.com

Ministry of Health and Populaltion, Nepal. (2020, july 10). https://covid19.mohp.gov.np/\#/. Retrieved from www.mohp.gov.np: www.mohp.gov.np

National Health Portal, India. (2015, May 07). https://www.nhp.gov.in/ayurvedic-perspectiveof-swine-

flu_mtl\#: :text=Symptoms\%20of\%20Swine\%20flu\%20in,mental\%20strength\%20at\% 20mental\%20level. Retrieved from https://www.nhp.gov.in:

https://www.nhp.gov.in/ayurvedic-perspective

Nemetchek, M. D., Stierle, A. A., Stierle, D. B., \& Lurie, a. D. (2016). The Ayurvedic plant Bacopa monnieri inhibits inflammatory pathways in the brain. Journal of Ethnopharmacology, 92-100.

Nile, S. H., Nile, A., Qiu, J. i., Li, L., Jia, X., \& Kaia, G. ( 2020, Pages, June). COVID-19: Pathogenesis, cytokine storm and therapeutic potential of interferons. Cytokine \& Growth Factor Reviews, 53, 66-70. 


\section{Nepal Journal of Multidisciplinary Research (NJMR) \\ Vol. 3, No. 1, June 2020. Pages. 1-6 \\ ISSN: 2645-8470 (Print), ISSN: 2705-4691 (Online) \\ DOI: https://doi.org/10.3126/nimr.v3i1.30213}

Pansare, T., \& Thombare, P. (2016 ). Review on Rasayana (Rejuvenative) Plants of Various Nighantus (Ayurvedic Materia Medica). International Journal of Ayurvedic and Herbal Medicine, 2369-2384.

Patil, V. M., Singhal, S., \& Masand, N. (2020). A systematic review on use of aminoquinolines for the therapeutic management of COVID-19: Efficacy, safety and clinical trials. Life Sciences, 1-10.

Puthiyedath, R., Kataria, S., Payyappallimana, U. k., Mangalath, P., Nampoothiri, V., Sharma, P., . . Trehan, N. (2020). Ayurvedic clinical profile of COVID-19 - A preliminary report. Journal of Ayurveda and Integrative Medicine, June. Retrieved from https://www.ayurvedatreatments.co.in/ayurvedatreatments.

Terry, M. (2020, June 30). Mutated COVID-19 Viral Strain in U.S. and Europe 10 Times More Contagious than Original Strain. (M. Terry, Editor, \& BioSpace, Producer) Retrieved 2020, from https://www.biospace.com/article/mutated-covid-19-viralstrain-in-us-and-europe-much-more-contagious/: https://www.biospace.com

The Ayurvedic Institute. (2020, June 30). https://www.ayurveda.com/ayurvedic-perspectiveon-covid-19. Retrieved from https://www.ayurveda.com: https://www.ayurveda.com

The Conversation. (2020, April 15). Coronaviruses - a brief history. Retrieved from https://theconversation.com/coronaviruses-a-brief-history-135506: https://theconversation.com

Verma, N., Goyal, M., \& Varsakiya, J. (2019). Nutraceuticals and Rasayan Chikitsa- A Review. Journal of Ayurvedic and Herbal Medicine, 25-27.

World Health Organization. (2020, July 10). www.who.int. Retrieved from https://covid19.who.int/: http://www.who.int

World Health Organiztion. (2020, April 24). "Immunity passports" in the context of COVID19. Retrieved June 29, 2020, from https://www.who.int/newsroom/commentaries/detail/immunity-passports-in-the-context-of-covid-19: https://www.who.int

$W w$. (n.d.). Retrieved from https://covid19.who.int/. 